\title{
JUDGEMENT STATE AUDITOR ON AUDIT OPINION FOR GOVERNMENT FINANCIAL STATEMENT WITH PERSPECTIVE HERMENEUTIC PHENOMENOLOGY
}

\author{
Dwi Setiawan Susanto $^{1 *}$, Made Sudarma ${ }^{2}$, Sutrisno $^{2}$, and Rosidi ${ }^{2}$ \\ ${ }^{1}$ Public Sector Accounting, BPK RI \\ ${ }^{2}$ Brawijaya University
}

\begin{abstract}
Public accountability quality of financial statement which audited by BPK RI should be based on State Finance Audit Standard (SPKN) and audit system or guidelines to attest the truth and fairness of the judgement. However, audit process is not only depends on structured standard system approach but also influenced by individual (auditor) subjectivity, which may play a role in the audit judgement and final audit opinion. Our study aims to analyze the role of BPK RI auditor subjectivity during audit judgement in government institution and in making final audit opinion, using interpretive hermeneutic phenomenology. We conducted in-depth interviews with BPK audit opinion signing auditors and analyzed how auditor interpreted audit data, in regards with the basic principles of public accountability, audit standard, law and regulation, internal control and complexity organization in the auditee institution. Our study found differences among auditors in interpreting audit data based on different perspective and understanding of standard system, law and regulation and complexity of organization, mostly because they did not use basic principles of public accountability during the process and making audit judgement and final audit opinion. Our results came to understanding that auditors should be using basic principles of public accountability when interpreting audit data, audit standard, law and regulation to improve quality of audit judgement. Auditors of BPK as supreme audit institution in Indonesia should combine all aspects in auditing process and making final audit judgment.
\end{abstract}

Key words : Audit Opinion, Public Accountability, Audit Judgement, Hermeneutic Phenomenology.

Vol. 27, No. 2 August 2019 


\section{INTRODUCTION}

The process of financial statement audit is based on the state finance auditing standard (SPKN). The auditing process set by the standard includes audit planning, execution, and reporting. Audit opinion process is a decision-making process by the professional audit judgement of state auditor. The decision-making process must consider public interest and others. Process to get reasonable assurance using professional judgement needs the auditor's understanding not only about accounting standard but also the compliance of law and regulation and internal control effectivity. Audit methodology includes sampling methods needs to be determine to get the fairness of government financial statement. The process is supported by auditor competency and skill in implementing SPKN, audit system, law and regulation. During the audit process and constructing final judgement, auditor subjectivity is difficult to be avoided.

Based on State Finance Audit Law number 15/2004, audit opinion is auditor professional statement about the fairness of financial information presented in financial statement based on: (i) compliance with government accounting standard, (ii) adequate disclosure, (iii) compliance on law and regulation and (iv) internal control effectivity. There are four audit opinion that can be issued by auditor: (i) unqualified opinion, (ii) qualified opinion, (iii) adverse opinion and (iv) disclaimer of opinion.

Audit reporting should consider materiality, risk and judgement. There are two concept of judgement correlation which are risk concept and materiality. Both concepts will have an impact on the fairness qualification of financial statement issued by the auditor. When executing the audit procedures, auditor must issue opinion with judgement based on past, present, and future events. Auditor judgement in audit process is influenced by technical and non-technical factors. Technically, auditor perspective in responding to audit information is related to responsibility and audit risk that faced by auditor due to judgement that they make. The non-technical factors which influence auditor's perspective in how to respond and evaluate information including basic auditing knowledge, experience, behavioral for getting and evaluating information, pressure from supervisor or auditee and complexity assignment when doing auditing. 
We conducted this study primarily to improve the quality of audit reports, which are very much determined by professional considerations as examiners in determining the impact of legislation and the appropriate methodology applied to the examination. Differences in the interpretation of laws and regulations will then cause many problems, the implications of which will greatly determine the professional judgement of the examiner. The same problem of non-compliance matter raises interpretations that can differ between examiners one and the other. The State Finance Auditing Standards $(\mathrm{SPKN})$ in the examiner's judgement process are only used as a benchmark, but other factors that are considered by the examiner are very complex.

The purposes of this study are : (1) to understand the interpretation of the concept and audit process by auditor in making decisions and opinions on government financial statements, (2) developing a new concept of the audit judgement for state financial examinations using criterias according to State Finance Audit Law no 15/2004, and (3) to develop a new understanding of the concept in state financial examination using qualitative research methodologies on auditors' judgements in giving opinions on government financial reports.

\section{STUDY LITERATURE AND REVIEW}

There are few studies reporting behaviour of auditor and other factors contributed in making judgement audit. Chung and Monroe (2001) reported that gender was significantly impacted auditor judgement, while Hartarto (1999) and Trisnawati and Iswati (2003) reported there was no performance difference influenced by gender. Ruegger and King (1992) reported that female auditor showed higher morality consideration compared to male auditor. Abdolmohammadi and Wright (1987) reported significant impact of complexity assignment to audit judgment, and Stuart (2001) reported that the impact of complexity assignment in unstructural accounting firm. These previous studies showed inconsistent results and were not appropriately reflected auditor behaviour in the real world.

There are constrains for auditor in a public accounting firm, in conducting audit financial statement or in achieving performance expectation. Some difficulties has come from their assignment for example work pressure, human recources incompetent or

Vol. 27, No. 2 August 2019 
uncertainty tasking. The conditions lead to inaccuracy of performance audit judgement which resulting in declining audit judgement quality (Libby and Lipe, 1992). For improving performance audit judgement, public accounting firm recognized important thing performance insentive in the organization. Implementing performance insentive can enhance effort and achieve higher performance (Libby and Lipe, 1992).

Although several studies have tested the relationship between performance insentive and performance audit judgement, evidence empirical that direct research effort as mediator still limited. Previous studies has shown that performance insentive can improve effort and performance audit judgement (Awashi and Pratt, 1990; Chang, 1997; Cloyd, 1997; Libby and Lipe, 1992). Performance is not only affected by performance insentive that apply, but with level complexity task facing in finishing audit assignment. Difference level of complexity task can influence an auditor in complishing audit task. Difference complexity task when high complexity task and also when low task complexity can can make different influence at performance audit judgement. This meaning that auditor can have difficult in judgement decision for variation audit assignment with several information type and enough procedure to do.

Haryanto (2012) studied an experimental method of framing phenomena in auditing tasks. Phrame phenomena in environment audit organization is very important. Emby (2994) and Suartana (2005) concluded that frame phenomena have distortion impact on audit judgement by auditor. Both studies used frame phenomena developed by prospect theory (Kahneman and Tversky ,1979; Tversky and Kahneman (1981). The prospect theory consisted of two domains which are profit (positive framing) and loss (negative framing).

The important thing for law and regulation auditor is social economy message to assess and conduct attestation validity financial statement that value is part of interpretation from condition corporate financial statement as explore Pentland 1993. Mc Lullich (2005) explaining generally main research audit judgement and decision making based on quantitative (Trotman, 1997). Usually any research strethening representation from audit strategy. This model focus on input and output from process decision making. It is limited in the process audit judgement, specially in the area of strategic formulation, audit strategy for audit judgement. For improving quality of audit judgement, it needs 
insight in process auditor individual judgement in wide environment, auditor needs to have an insight of the entity's environment when making an audit judgement, specially to test judgement in contex independent and subjective.

Mcullich (2005) explored hermeneutic aspect of auditing practice based on auditing and accounting literature by Francis (1994) and audit judgement discussion as hermeneutic practice by Llewellyn (1993), Willmot (1993) and Boland (1989). Hermeneutic contribution to accounting research (Lavoei, 1987) examined hermeneutic application to understand accounting as business language. Mcullich (2005) analyzed audit practice as hermeneutic study and give insight into discrepancy between audit standard and audit experience including perspective and subjectivity of auditor.

Based on previous studies, so far there was no reports of exploration study on interpretation of facts tested in government entity audit with the complexity evidence including financial evidence, law and regulation compliance evidence as basic criterias for auditor judgement. Our study is using interpretive approach to get more insight about auditor perception in formulating judgement process, especially for opinion report in context of structural condition which use standard ( In process planning, execution and reporting) and organization relationship. Question how individual auditor make sense and dialectica with structure inside audit standard, audit system, and reality that faced in the context state finance audit. For question and answer interview that design to describe and enter in dialogue with individual auditor discourse that concern with their perception and attitude for performance assignment state finance audit.

In daily practice judgement exists between two aspects. The first aspect is regulatory compliance and the second one is creativity conduct of the auditor, so that judgement can override aspects of standard structures and systems but emphasize the individual auditor. The existence of standards and procedures considered in judgement as part of the auditor in the process of interpreting the auditee situation and the application of detailed rules in the audit assignment. The structure does not limit judgement but rather allocates judgement and direct in a certain way in the examination process, for example the structure provides many guidelines as well as rules as a benchmark for action but the final formulation is still a discretionary decision made by the individual auditor. Interpretive strategies involve something radical from accepted norms or intuition making

Vol. 27, No. 2 August 2019 
decisions that appropriately understands the process carried out by the auditor and the environment being examined (subjective understanding), which encourages openness through text and financial reporting. Judgement will allow evaluation to bring unity and truth to the financial statement text.

\section{RESEARCH METHODOLOGY}

Study Approach

Our study is designed as a qualitative research, which aims to understand the phenomenon of what is experienced by the subject of research, such as behavior, perception, motivation, action holistically and by way of descriptions in the form of words and language, in a special context that is natural and utilizing various natural methods (Moleong, 2008: 6). This qualitative approach is used with a variety of considerations, namely: first, the data source and data of this study are natural. That is, that what is examined is a natural phenomenon or what it is by considering the context in which the phenomenon occurs. Second, human instruments. In this study the researcher himself is the main data collection tool so that researchers can easily adjust to the reality that is on the ground, which cannot be done other than humans and is able to understand reality in the field by participating in research sites (Moleong, 2008). Third, this study emphasizes more on the process aspects and the meaning of a text from the interpretation of the research subject and focuses on phenomena (social reality) holistically and does not reduce the phenomenon into variables which are then partially sought, but the phenomenon is seen as part of a whole. Fourth, the results of the interpretations obtained and agreed upon by the research subjects were used as data sources (Moleong, 2008).

This study seeks to understand the meaning according to the information provided by informants because this research is a social analysis that uses a subjectivity 
approach, which tries to understand the situation as it is, so the paradigm that is more suitable to be used in this study is the interpretive paradigm. The use of this interpretive paradigm has provided a deeper understanding of the auditors "judgement" process from the perspective of the informant in his life as the subject of research.

The interpretive paradigm emphasizes the aspects of the process, interpretation and meaning of an action to understand holistic social reality with the assumption that understanding human actions is not enough with surface behavior but also in human actors to get a complete picture of humans and his world. Based on this assumption finally social reality is seen as a subjective entity, created, and interpreted. The implication is that research is considered a tool used to interpret the world, understand social life, and emphasize meaning and understanding (Sarantakos in Triyuwuono, 2006). As stated by Chua (1986) action can only be understood by referring to its meaning.

\section{Hermeneutic Phenomenology}

Each methodology used in hermeunetic is a believe of perspective which has different philosophical assumption and leads to different approach in a social science concept. Our study assumed that knowledge is a social interaction process to give direction to the formation of reality and a better social order.

The researcher wants to explore how the decision making process of state financial auditors that structurally uses the State Financial Audit Standards (SPKN) in determining the criteria for granting state audit opinion according to Law No. 15 of 2004 which consists of: (i) conformity with government accounting standards, (ii) compliance with laws and regulations (iii) adequacy of disclosures (adequate disclosures), and (iv) effectiveness of internal control systems. On the other hand, the auditor also has an element of subjectivity in making decisions on giving opinions on government financial reports. Noting the purpose of research to explore interpretations of understanding behind auditors' decision making as human subjects who are social beings in conducting audit judgements, researchers will use a qualitative approach to interpret the phenomenon of the audit report text in the form of an opinion on government financial statements.

Ricoeur's hermeneutic phenomenological approach is very relevant in examining the audit process carried out by the state financial 
auditor, using the text approach contained in the audit standards. Audit systems and procedures can be interpreted in the audit process carried out by the state financial auditor and how sufficient evidence can be relevantly disclose the examination. Individual judgement factors that have inherent subjectivity and fulfillment of standards and structural inspection systems can be unsynchronized in the determination of the auditor's judgement. At the end, the individual responsible for the examination will make judgement decisions on the opinion of the examination given.

\section{The Phenomenology Perspective As A Study}

Phenomenology comes from the Greek word fenomenon, which is something that appears, which is seen because it is covered. In Indonesian, the term symptom is commonly used. So, phenomenology is a school that talks about phenomenons or everything that manifests itself. The qualitative research methodology using the phenomenology method helps researchers enter the perspective of others and try to understand why they are so. Phenomenology methods not only see the perspective of participants, but also understand the framework that has been developed by each individual, from time to time, to shape their responses to events and experiences in their lives. Phenomenology overrides the researchers' initial ideas about an event or experience with the aim of understanding it from the world where the participants are.

In effort to see the nature through intuition, Husserl introduces a reduction approach that is delaying all existing knowledge about objects before intuitive observations are made. Reduction can also be caused by selection. Another term is epoche, reduction which means the placement of something between two brackets, by forgetting the meanings of objects for a while, and trying to see objects directly with intuition without the help of pre-existing meanings.

It is at this point that hermeneutics occupies an important position. Hermenuetic proposes a method of understanding (versetehen) to the world of life. Hermeneutics asserts that a typical human phenomenon is language, and therefore understanding 
humans can begin with language. Language is the objectivity of human consciousness of reality (birth and mind). Language reflects the reality experienced by the speaker, as well as what the speaker thinks. Through language, humans also give meaning, and meaning is an object of social science such as in communication (communicology).

\section{Hermeneutic of Ricoeur's Phenomenology as a Way of Finding Meanings}

Etymologically, the word hermeneutics comes from Greek, hermeneuein, which means to interpret. In Greek mythology, this word is often associated with a character named Hermes, a messenger who has the task of conveying Jupiter's message to humans. The task of delivering a message also means translating the words of the gods into a language that can be understood by humans. Translation is actually identical with interpretation. From there then the understanding of the word hermeneutics has to do with an interpretation or interpretation.

The question is, how can objectivity be achieved or can the subjectivity of the interpreter be avoided? Ricoeur offers four methodological categories as the answer, namely objectivity through structure, distortion through writing, distortion through the world of text, and appropriation (self-understanding). The first two are objective poles. This is important as a prerequisite for the text to say something. Objectivation through structure is an attempt to show internal relations in structure or text. Here it appears that hermeneutics is closely related to structural analysis. Structural analysis is a logical means of deciphering text (the object being interpreted).

Hermeneutic phenomenology is a synthesis of several hermeneutic methods and phenomenological methods (Ricoeur, 1985, 1991). While criticizing Husserl's idealism, Ricoeur shows that hermenutics cannot be separated from phenomenology. Phenomenology is an irreplaceable basic assumption for hermeneutics. On the other hand, phenomenology cannot carry out its program to understand various phenomena as a whole and comprehensively without interpretation of the subject's experiences. For the purposes of interpretation it requires hermeneutics. In general, phenomenology is the study of how humans as subjects interpret the objects around them. According to Ricoeur (1985), as far as the meaning and meaning of humans is done, hermeneutics are involved there. So basically phenomenology and hermeneutics complement each other. On that basis, Ricoeur developed a hermeneutic phenomenology method.

Vol. 27, No. 2 August 2019 
Scott-Baumann (2003) assesses the method developed by Ricoeur is a method that can resolve the dilemma between the quantitative paradigm and the qualitative paradigm based on the epistemological conflict between Explaining or Enklären (explaining the symptoms and predicting and controlling) and Understanding or Verstehen (understanding through interpretation of symptoms) and bringing them together in a coherent and consistent research method.

Ricoeur (1985) defines hermeneutics as the theory of operation of understanding in relation to interpretation of the text. According to him, what is said or written by humans has more than one meaning if it is connected with a different context. The characteristic that causes words to have more than one meaning when used in different contexts by Ricoeur is called 'polysemi'. It is these characteristics that make hermeneutics necessary for understanding humans.

Although Ricoeur essentially operates by entering into the orientation of the reader in understanding the text, he feels uncomfortable with the intrinsic subjectivity associated with hermeneutics. He tried to find the basis of objectivity in understanding a text while still maintaining the openness of interpretation of what the text revealed.

"Hermeneutics of suspicion" put forward by Ricoeur represents his efforts to maintain hermeneutics as science and art. According to Ricoeur (1970), hermeneutics is turned on by two motivations, the will to be suspicious and the willingness to listen; willingness to oppose and willingness to obey. With that basis, in the context of understanding the text, the first thing to do is try to stay away from idols by consciously aware of the possibility of the blend of our expectations in understanding a text so that the understanding of the text does not come from within us as readers. Second, there is a need to listen to openness to the symbols and flow of the text, thereby enabling creative events to occur before the text and affect us.

Phenomenology hermeneutics also share the notion that linguistic meaning is inherited from experienced experiences. In an effort to understand phenomena, consciousness that is always fixed on objects uses perceptual devices (noesis) to obtain a complete perceptual picture of the phenomenon (noema). The formation of a complete perceptual picture requires adequate linguistic equipment to carry out interpretations, predictions, syntactic relationships and so on so that the picture can be articulated. In 
terms of hermeneutics, linguistic placement as a vehicle used to understand analysis of pre-linguistic perceptual images is the principle underlying the process of interpretation.

Ricoeur wears the properties of the text into action. Just as text is a frozen discourse, action also in the beginning is a discourse in the sense that the events of the action that occur in the time frame, involve certain actors (actors and those who are affected) with certain purposes as well. Stabilization of action makes action no longer only refer to one particular event, thus actions are also exposed to the characteristics of the text.

After being established as text, human experience and actions can be open to interpretation and the results of their interpretation include objective meaning and subjective meaning. Objective meanings differ from their subjective meanings but both complement each other and enrich interpretation. Appropriate understanding cannot be produced only by returning to the intention of the person who experiences or acts of action. The construction of meaning must be in the form of a dialectical process between estimation and endorsement.

\section{Research methods}

Creswell $(2007,59)$ explains that as an educator Van Manen has written a hermeneutic book on phenomenology which is described as life-experience-oriented research (phenomenology) and interpretation of living texts (Van Manen, 1990: 4). Phenomenology is not only a description of events but also an interpretive process carried out by researchers from the meaning of life which in the context of examination is certainly how the examiner experiences phenomena in the conduct of examination assignments especially in making professional judgment decisions on the giving of opinions.

\section{Selection of Informants}

The informant of this study, as explained by Salim (2006: 131) is a member of the group under study who will deliver the researcher to the heart of the problem that he wants to know and investigate. The selection criteria for informants are based on : (1) the subject (person) who knows and understands well about the activities that are the focus 
of research (object of study); (2) active direct involvement in state financial audit activities, especially those related to process judgment in giving opinions. Therefore, researchers will get rich data if they determine an "insider" as information.

From these criteria, the informants selected in this study were subjects who were directly involved in the judgment process of giving audit opinions, namely accountants auditors who got assignments related to judgement in giving opinions, e.g quality controllers, technical controllers and senior auditor leaders in the assignment of examinations of government financial reports for both local and central government financial statements.

\section{Unit analysis}

The unit of analysis referred to in this study as explained by Hamidi (2004: 75) is the units studied can be individuals, groups, organizations, objects or a setting of social events such as individual and group activities as research subjects. The research analysis unit were auditors, especially the technical controllers and quality controllers at the Audit, the BPK Representative Office who issued the audit report. This research will be conducted in one of the Auditors and BPK Representative Offices who have been assigned to audit government financial statements.

\section{Data Collection Procedure}

In accordance with the research problems, the data needed in this study are documentation studies such as Examination Results Reports, Regulations related to examinations, State Financial Audit Standards (SPKN), regulations in the field of state finance, Audit Management Guidelines (PMP), inspection guidelines operational guidelines and technical guidelines.

Data collection techniques are important step in qualitative research, because without proper data collection techniques, researchers will not get data that meets established data standards. Data collection techniques used in this study are as follows: first observation or observation; second interview; and third, documentation. Research using an interpretive approach focuses more on the reality of reality which has practical 
interpretation or as an approach to human nature which includes the meaning of real behavior.

These aspects are the background or pervasive of human social actions as reflected in the process of giving opinions on the results of examinations of the financial statements of local governments and other matters related. In order to in-depth interviews, interview guidelines are drawn up to seeking information to answer research problems. The information obtained will be recorded manually and/or recorded using a recording device with the consent of the informant.

Documents are records of past events, can be any evidence process based on any type of source, whether written, oral, illustrative, or archeological. The document is important, especially research interests for authentic evidence and may also be a supporter of truth (Satori \& Komariah, 2010). Furthermore, Satori and Komariah reveal that in the historical method, the discussion of the analysis of document content is important which will maintain the credibility of the research results. The most important thing in the content study is internal criticism (credibility) and external criticism (authenticity) of data sources. Critical theory also emphasizes history, with the assumption that what is currently, for example, there is a dominant discourse in society that does not occur immediately, but through a historical process (Agger, 2003). Therefore, what is done by organizations can be traced by using document traces in sharing various types of sources.

\section{Data analysis technique}

Data analysis is an attempt to find and organize systematically the results of observations, interviews, and others to improve the understanding of researchers about the case under study and present it as findings for others (Muhadjir, 2000).

The next step is arranged in units, then categorized or coding. The final stage of this data analysis is to hold a validity check of the data. After completing this stage, begin to interpret and interpret. The analysis technique in our study is by synchronizing the structure and individuals that are understood and practiced by the examiner in the judgment process of giving opinions, by taking the site to the examiner at the Auditor and the BPK Representative Office. 


\section{RESULT}

The interpretation difference of state auditors regarding the provision of audit opinions are related to the SPKN criteria and the State Finance Audit Law turns out to pay attention to different contexts of different interpretations. The difference is mainly in the interpretation of the context of financial statements as the presentation of numbers according to criteria with an emphasis on the presentation or financial statements as the accountability of state finances to the public with broader assertions, for example related to aspects of compliance with laws and regulation.

The auditor's view of the MYJ has the following views:

"What distinguishes the examination of state finances, especially aspects of compliance with laws and regulations, because the dimensions are very broad and the main thing is in providing aspects of state financial accountability. The audit technique can be the same between public sector audits and state finances, but this aspect of laws and regulation is very basic in its paradigm that differentiates it from business sector audits. "

So understanding of the aspects of criteria in examining state finances, namely government accounting standards, effectiveness of internal control systems, adequacy of disclosures and compliance with laws and regulations greatly determines how audit judgement provides opinion on government financial statements.

The MYJ view is further linked to the application of compliance on laws and regulations as a criterion in providing opinions on financial statements as follows:

The position of laws and regulation is the basis in the application of government accounting standards. It must be observed how these laws and regulations can have an impact on the presentation of financial statements. Laws and regulation should be seen as having an impact on the presentation of financial statements. For example, policies related to the provision of benefits to the DPRD's income, then the legal basis determines the amount of income and if there is noncompliance with regulations and results in misstatement of financial statements this should be adequately disclosed. 
So understanding of the aspects of criteria in examining state finances, namely government accounting standards, compliance with laws and reguations ,effectiveness of internal control systems, and adequacy of disclosures greatly determines how audit judgement provides opinion on government financial statements.

The MYJ view is further linked to the application of compliance regulations as a criterion in providing opinions on financial statements as follows:

The position of legislation is the basis in the application of government accounting standards. It must be observed how these laws and regulations can have an impact on the presentation of financial statements. Laws and regulation should be seen as having an impact on the presentation of financial statements. For example, policies related to the provision of benefits to the DPRD's income, then the legal basis determines the amount of income and if there is noncompliance with regulations and results in misstatement of financial statements this should be adequately disclosed.

Audit findings related to aspects of non-compliance in determining the DPRD salary and benefits are material findings and have an impact on the presentation of government financial statements. Laws and regulations related to spending on grants, social assistance also occur a lot of non-compliance which has a direct impact on financial statements. MYJ adds the interpretation that:

If the findings related to non-compliance are adequately disclosed, the opinion on the financial statements can be reasonable in so far as the disclosure is adequate. For example, for finding a state loss if it has been determined adequately in the financial statements clearly and transparently, the opinion can still be reasonable. How financial report readers can read financial statements can read financial statements adequately to be able to find out that there is a problem of state losses in the accountability of financial statements that will be processed according to laws and regulations, opinions can remain reasonable. 
Ricoeur (2012) states that the main task of hermeneutics is on the one hand looking for internal dynamics that govern the structural work in a text, on the other hand it seeks the power possessed by the text work to project itself out and allow the "things" of text to surface. In the context of public accountability, the context of the organizational environment and the characteristics of the text are different because different organizational missions, regulations and control systems reveal what is in the text which is then presented to internal and external parties. The disclosure aspect as a manifestation of public accountability is the most important part in state financial accountability, so that public assessments will be provided with information disclosed transparently and accountably in assessing how state finances are managed and then accounted broadly.

In methodological terms, this implies that management scholars may legitimately adopt hermeneutics as a research approach not only for interpreting the usual corporate documents (e.g., annual reports, internal memoranda, policy documents, etc.) but for investigating a whole host of microlevel and macrolevel organizational phenomena such as technological change, leadership,motivation, empowerment, corporate strategy, and many more ( Prashad , 2002) . In the context of complexity government organization will be analyse by auditor in considering audit judgement to give understanding in broad perspective.

The understanding of the state auditor on the interpretation of the SPKN requires a re-understanding of the purpose of giving opinions on government financial statements in order to increase public accountability. This is a philosophical meaning that determines the concept of opinion on financial statements in considering the criteria for giving opinions on government financial statements. The researcher provides an overview that distinguishes the interpretation of state auditors in giving opinions is how to understand the philosophical conception within the SPKN to determine opinions on government financial statements. This is revealed by MYJ as follows:

The four criteria in the disclosure and compliance law are not only annual performance but also accountability, not all transactions can be corrected, for example 
cash is reduced to the recognition of third parties, but become other assets and cannot be corrected due to the classification of budget documents in the form of regulations.

The alternative is that disclosure of not misinterpretation is disclosed and if material then affects opinion In the MYJ explanation, it was stated that the text of the criteria used as the basis for audit judgmendistinguishes the context of examining government entity financial statements with the financial statements of business entities. The budget implications based on laws and regulations that make the basis for changes in accounting corrections cannot be done without a legal basis which is the main legal aspect compared to the assertion of the accounting transaction, so that the accounting corrections cannot be made and the recognition and disclosure are still stated on the asset account others have not been as corrections to the cash account and if the numbers are material then the consideration of audit judgment in giving opinion.

While the views of other state auditors state that opinions given to financial statements of government entities do not differ from business entities having different understandings, and hold that the audit process is exactly the same as the audit of financial statements of business entities only as different entities as stated by IN:

Yes, the process is the same, so if a correction to the transaction is presented, it will be journalized for correction so that the numbers according to the corrections can be directly carried out and corrections to the transaction according to the correction of the numbers and accounts presented

The difference in this context in the interpretation of the text implies different treatment for the audit judgment consideration process so that the phenomenon that occurs in the process of judicial audit consideration by the state auditor as the subject of the text object criteria and considerations given also different interpretations of the opinions given. Differences that occur in interpreting standard text with different interpretations with approaches that are not merely the text presented but how the context of the phenomena that are the basis of basic differences in audit judgement decisions. This requires awareness by combining the understanding of the text with regard to phenomena that are certainly related to the context that makes an approach to knowledge and experience which is then developed into a hermeneutic approach and phenomena (Recour, 2012). 


\section{The Meaning of Audit Opinion in Context, Text and Phenomena}

The difference of audit opinion meaning captured by the state auditor's subject for understanding this text has implications for the judgment of the audit judgment of the state auditor in giving opinions on financial statements reviewed from the aspect of criteria for compliance with the laws and regulations. The position of the legislation even became antithetical to principle based which became an accounting development and examination of the public sector because the principle of substance over form changed its meaning to form over subtance. The problem is not just a correction or not correction of the transaction but on the interpretation of the assertions stated in the financial statements.

Assertions associated with the compliance aspect are the basis of audit judgment considerations which are the main considerations in making audit judgment decisions on opinions expressed in government financial statement audit reports. Furthermore, the MYJ revealed its understanding of the meaning of the text of the criteria for compliance with laws and regulations as follows Legislation related to the presentation and disclosure if budgeting and assertions are fulfilled, then the opinion is reasonable, non-compliance which is not related to opinion is reasonable. The party who is not yet clear about other assets, the account is not yet clear, part of the disclosure opinion clearly in the financial statements, even if there is corruption if it has not been presented in the presentation in the financial statements, the opinion becomes unnatural.

Consideration of audit judgment on this text phenomenon is in line with Ricour's (1985) view associated with the context of understanding different texts. The position of the legislation in the text of the compliance criteria remains in accordance with the disclosure of the purpose of the examination which is essentially an opinion on financial reporting so that when the assertion aspect is fulfilled and the implication is expressed in sufficient disclosure text, the opinion given remains unqualified. Corruption cases that are in the public spotlight and are often associated with fair opinions on financial statements do not automatically become a consideration of opinions if they have been adequately disclosed, the opinions given are still reasonable. This is also a consideration of audit judgment on opinions that are often associated with corruption cases that have occurred in government entities lately. 
Ricoeur said that there was a paradox of ideological public accountability that was unreliable in terms of accountability when there was a text that was indicated by a disclaimer opinion and a fragile control environment with collusion, corruption and nepotism which became an acute phenomenon in that case. The opinion statement provides meaning to express the failure of public accountability.

How information is clearly stated on the face sheet of opinions and financial statements with the following disclosure of his opinion:

The issue of mark up with a price of 10 million which should only be 2 million for the purchase of computers and presented in financial statements in accordance with transactions that occur if there are doubts about the transaction and presentation, the actual price is disclosed until there is evidence of proof of whether it can be covered in the financial statements. Fairness is assessed from the reader of the financial statements. Until proven until it can be proven, then it is corrected if enough evidence to be disclosed. As long as the presentation is presented in real terms, then it is. According to the important experience face sheet that must be maintained if there is a doubt explained in the notes to the financial statements Opinion is a face sheet presented in the face sheet if the corruption with the explanatory paragraph

Proof with evidence that could indicate that there was a mark-up with supporting evidence to state that there was a problem with the procurement of the computer that must be obtained and become the basis for the financial / state losses. Furthermore, the loss of the country will become a receivable to be settled legally by the state finances and if manipulation is proven to occur then it will be followed up by a legal process. The researcher interpreted the text and the following phenomena using Ricoeur's phenomenological hermeneutic approach, where the subject's understanding of state auditors in interpreting audit judgment by positioning the text in accordance with Law No. 15 of 2014 legally compared to understanding such opinions in business entities would have very different implications for audit judgment.

The context of opinion is given in accordance with the consideration of the four criteria in an integrated manner with the aim remaining at the examination of the financial statements aimed at assessing the fairness of the presentation of financial statements. Professional Sceptism Auditor of the State The attitude of caution is skeptical about the

Vol. 27, No. 2 August 2019 
environment of government organizations that have high risk, because this is the most important thing to keep the audit failure from happening because of the risks faced by government entities in managing state finances with a conflict of interest in the process of determining regional heads for example.

Audit opinion will refer to materiality concept that Kristensen (2015) conclude the analysis has demonstrated that, besides a significant quantitative element concerning the client in question, making a materiality assessment also includes significant qualitative components. The quantitative component is mostly related to the audit task, whereas the qualitative components are reflected in all three features of the general audit judgment and decision-making theory. That three features are audit task, auditor, auditor interaction with stakeholders booth considering the quantitative and qualitative factor in materiality concept.

International Federations of Accountants (2018) defines professional skepticism as: "Sceptism means that the auditor makes a critical assessment, with a questioning mind, the validity of audit evidence is obtained and is alert to audit evidence obtained and is alert to auditing evidence that contradicts the reliability of documents and responses to inquiries and other information obtained from management and those charged with governance" "Hermeneutics of suspicion" put forward by Ricoeur represents his efforts to maintain hermeneutics as science and art. According to Ricoeur (1970), hermeneutics is turned on by two motivations, the will to be suspicious and the willingness to listen; willingness to oppose and willingness to obey. With that basis, in the context of understanding the text, the first thing to do is try to stay away from idols by consciously aware of the possibility of the blend of our expectations in understanding a text so that the understanding of the text does not come from within us as readers. Second, there is a need to listen to openness to the symbols and flow of the text, thereby enabling creative events to occur before the text and affect us.

SY state auditor who acts as the person responsible for delivering:

"Judgment auditors are associated with risk of non-compliance in the form of fraud by using the budget modus operandi required by the auditor's experience by emphasizing risk in important positions so that cases of irregularities can spread everywhere when involving top leaders of conspiracy regional leaders and DPRD leaders, 
if they occur fraud then the impact can be extended to accountability and the most important thing is the occurrence and existence "

In hermeneutic phenomenology, Ricoeur (1985) emphasizes the importance of understanding about distanciation. The hermeneutic return to phenomenology occurs through distance-taking. Every meaning carried out by consciousness involves taking distance from an object that is given meaning, taking distance from the experience experienced while remaining pure and straight towards him.

This takes into account the many conflicts of interest, so that the independence in decision making and also the relationship of conflict of interest is important to be considered.

This is in line with the consideration of audit judgment stated by the state auditor MAS as follows:

"Audit quality controllers not only pay attention to materiality planning limits but must pay attention to qualitative fraud risk and this requires experience of state auditor flight hours"

Auditing financial statements is an effort that is oriented to the risks and misstatements mentioned in management assertions that may be hidden so that the audit must be planned in such a way as to achieve a reasonable assurance that the misstatements will be found (Tuanakotta, 2011)

Through the discourse developed in the study of the hermenutics of the Ricour phenomenology, it can be synthesized a combination of audit judgment that considers the comprehension of criterion text in accordance with the context of state finance comprehensively in accounting standard texts, regulation compliance and legislation, effectiveness of internal control systems and adequacy of disclosure audit judgment decision opinions on the financial statements of government entities intact and not only pay attention to the substance over form but also consider form over substance within the scope of state finance while paying attention to the audit objectives to assess the fairness of government entity financial statements by combining text and phenomena which are the subject matter of the state auditor with a broad view of consideration in auditing judgments on the opinions of financial statements of government entities.

Vol. 27, No. 2 August 2019 


\section{Phenomenology Hermeneutics Understanding of Opinion Judgment Audit}

Through the review of audit with the phenomenology hermeneutics approach, it can be examined that the audit judgment factor on government financial statements is complex because the text used does not only consider the standard aspects of both accounting standards and examination standards but the text of compliance criteria with regulatory provisions is a materiality consideration for the presentation of financial statements. and assessment of the internal control system and the adequacy of disclosures. The structure approach by using standards to be the basis of objectivity is largely determined by the interpretation of the state auditor in determining audit judgement considerations given by using a professional judgment approach with due care, integrity and objectivity.

This requires that an approach that does not only use principles based must be combined with rules based because it involves laws and regulations that form the basis of considerations that are superior to the standard or set and the basic principles. The alternative solution is the rules based on principles approach, which is a combination of state financial legislation as a criterion developed and compiled according to the basic principles of good state / regional financial governance. So that there is no clash of understanding between the laws and regulations with the basic principle.

BW state auditor gives his views as follows:

"The most important thing is the goal of the state in the examination of state finances to be achieved dependent by government organizations so that opinions are built to achieve the goals of the state, not just a number but how the numbers are built so that there is a control environment that covers the objects - processes - objects"

BW conducted a discourse that all of these components must be synchronize in their control not only on the process side, namely the methodology but from the auditor both individually and institutionally and of course the auditee and its organizational environment. Phenomena that occur in the organizational environment and interaction patterns are also a consideration in taking audit judgment decisions on giving opinions on government financial statements. The problem of collusion, for example, is still a modus 
operandi that greatly determines the accountability of organizations and individuals and groups within the system.

\section{Text of Criteria for Examination of Financial Statements}

Examination of government financial statements is designed to provide opinions on financial statements so that an understanding of the auditor's interpretation of compliance with laws and regulations and the effectiveness of SPI and the adequacy of disclosures is largely determined by the state's audit position. So that the implications will be in accordance with the understanding of the text of the government's financial statement audit criteria. Understanding the regulatory position, the purpose of financial reporting and the problem of eradicating corruption as the main agenda must be integrated appropriately so that the determination of audit judgement on the process of giving opinion is based on understanding the audit criteria clearly.

\section{CONCLUSION}

Rules based on principles are a solution to integrate elements of structure, systems, standards and procedures will be appropriate and driven by the basic principles of both accounting and auditing. This makes the misalignment of interpretations manageable with the audit policy process that is in line with the development of standards, systems and criteria for examinations. It's just that the criteria are expected to be more balanced combining regulatory elements and the underlying principles.

Differences in audit judgement occur because many auditors issue audit opinion solely based on a structural audit approach, wheereas state auditors should also consider the relevance of legislation and basic principles of accountability.

Audit judgment in the formation of a financial statement opinion must consider 4 criterias set by State Finance Audit Law No. 15/2004 that are integrated with an understanding of the principles of accountability. This approach can be declared as "Rules based on principles"

Based on the hermeneutical phenomenology approach, a state auditor must have experience and a complete understanding of public sector organizations, to be able to provide a good quality of audit judgement. 
50 Judgement State Auditor on Audit Opinion for Government. . . . .

\author{
Abbreviation : \\ BPK RI : Badan Pemeriksa Keuangan Republik Indonesia \\ DPRD : Dewan Perwakilan Rakyat Daerah \\ PMP : Panduan Manajemen Pemeriksaan \\ SPKN : Standard Pemeriksaan Keuangan Negara
}




\section{BIBLIOGRAPHY}

Abdolmohammadi, M., \& Wright, A. (1987). An Examination of Effect of Experience and Task

Complexcity on Audit judgment. Journal of The Accounting Review, LXII (1), $1-13$.

Agger, B. (2003). Teori Sosial Kritis: Kritik, Penerapan dan Implikasinya. Yogyakarta, Indonesia: Kreasi Wacana.

Awasthi, V., \& Pratt, J. (1990). The effects of monetary incentives on effort and decision performance: the role of cognitive characteristics. The Accounting Review, 65(4), 797-811.

Burrel, G., \& Morgan, G. (1979). Sociological Paradigms ang Organizational Analysis: Elements

of the Sociology of Corporate Life. London, England: Heinemann.

Chang, C.J., Ho, J.L.Y., \& Liao, W.M. (1997). The effects of justification, task complexity and

experience/training on problem-solving performance. Behavioral Research in Accounting, 9, 98-116.

Chua, W.F. (1986). Radical Developments in Accounting Thought. The Accounting Review, 61(4), $601-632$.

Chung, J., \& Monroe, G. (2001). A Research Note on The Effect of Gender and Task Complexity on Audit judgment. Journal of Behavioral Research, 13, 111125.

Cloyd, C.B. (1997). Performance in tax research tasks: the joint effects of knowledge and accountability. The Accounting Review, 72(1), 111-131.

Creswell, J. W., \& Miller, D. L. (2000). Determining Validity in Qualitative Inquiry. Theory Into

Practice, 39(3), 124- 130

Emby, C. (1994). Framing and presentation mode effects in professional judgment: auditors'

internal control judgments and substantive testing decisions. A Journal of Practice and Theory, 13, 102-115.

Vol. 27, No. 2 August 2019 
Francis, J. E. (1994). Auditing, Hermeneutics, and Subjectivity. Accounting, Organizations and

Society, 19(3), 235-269.

Hamidi. (2004). Metode Penelitian Kualitatif: Aplikasi Praktis Pembuatan Proposal dan Laporan

Penelitian. Malang, Indonesia: UMM Press.

Hartanto, S. Y. (1999). Analisis Pengaruh Tekanan Ketaatan Terhadap Judgment Auditor (Posgraduate thesis), Universitas Gadjah Mada, Indonesia.

Haryanto. (2012). Interaksi Individu - Kelompok sebagai Pemoderasi Pengaruh Framing dan urutan Bukti terhadap Audit Judgment Studi pada Sektor Pemerintahan (Dissertation), Universitas Brawijaya, Indonesia.

Husserl, E. (1931). Ideas: General introduction to pure phenomenology (W. R. Boyce, Trans.). London, United Kingdom: Allen \& Unwin.

International Federation of Accountant. (2018). Handbook of International Standards on Auditing and Quality Control. Retrieved from: https://www.ifac.org/publications-resources/2018-handbook-internationalquality-control-auditing-review-other-assurance

Jamilah, S., Fanani, Z., \& Chandrarin, G. (2007). Pengaruh Gender, Tekanan Ketaatan, Dan Kompleksitas Tugas Terhadap Audit Judgment. Simposium Nasional Akuntansi X, Makassar, Juli.

Kahneman, D., \& Tversky, A. (1979). Prospect Theory: An Analysis of Decision Under Risk. Econometrica, 47 (2), 263-291.

Kristensen, R.H (2015). Judgment in An Auditors Materiality Asessment. Danish Journal of Management \& Business nr. 2 | 2015.

Lavoie, D. (1987). The Accounting of Interpretations and the Interpretation of Accounts: The Communicative Function of the Language of Business. Accounting, Organizations and Society 12(6), 579-604.

Libby, R, \& M. G. Lipe. 1992. Incentives, effort, and the cognitive processes involved in accounting-related judgments. Journal of Accounting Research (Autumn), 249273 
Llewellyn, S. (1993), Working in Hermeneutic Circles in Management Accounting Research: Some Implications and Applications. Management Accounting Research, 4, 231-249.

Moleong, J. (2008). Metodologi Penelitian Kualitatif. Bandung, Indonesia: PT Remaja Rosdakarya.

Muhadjir, H. N. (2000). Metodologi Penelitian Kualitatif: Edisi IV. Yogyakarta, Indonesia: Penerbit Rake Sarasin.

Pentland, B. T. (1993). Getting comfortable with the numbers: Auditing and the microproduction of macro-order. Accounting, Organization and Society, 18(7-8), $605-620$

Prashad , A. (2002). The Contest Over Meaning: Hermeneutics as an Interpretive Methodology for Understanding Texts , Organizational Research Methods $2002 ; 5 ; 12$.

Ricoeur, P. (1974). The Conflict of Interpretations: Essays in Hermeneutics, Ihde, D. (Ed.), Evanston, United States of America: Northwestern University Press. Ricoeur, P. (1981). Hermeneutics and the Human Sciences: Essays on Language, Action and Interpretation, Thompson, J. B. (Ed.). Cambridge, England: Cambridge University Press.

Ricoeur, P. (2012). Teori Interpretasi, Memahami Teks, Penafsiran, dan Metodologinya (M. Hery, Trans.). Yogyakarta : IRCiSoD

Ricoeur, P. (2012). Hermeneutika Sosial. (M. Syukri, Trans). Bantul, Indonesia: Kreasi Wacana.

Ruegger, D., \& King E. W. (1992). A Study of The Effect of Age and Gender Upon Student Business Ethics. Journal of Business Ethics, 11, 179-186.

Salim, A. (2006). Teori \& Paradigma Penelitian Sosial, Buku Sumber Untuk Penelitian Kualitatif. (2nd ed.). Yogyakarta, Indonesia:Penerbit Tiara Wacana.

Satori, D., \& Komariah, A. (2010). Metodologi Penelitian Kualitatif. (2 ${ }^{\text {nd }}$ ed.). Bandung, Indonesia: Penerbit Alfabeta.

Sarantakos, S. (1955). Social Research. Australia: Macmillan Education Australia PTY LTD. 
Scott-Baumann, A. (2003). Reconstructive Hermeneutical Philosophy: Return Ticket to Human

Condition. Philosophy \& Social Criticism, 29 (6), 703 - 727.

Standar Pemeriksaan Keuangan Negara (SPKN). (2007). Peraturan BPK No. 1 Tahun 2007. Indonesia: Badan Pemeriksa Keuangan.

Stuart, I. (2001). The Influence of Audit Structure on Auditor Performance in High and Low Complexity Task Setting. Journal of Accounting Behavior, 3-30.

Suartana, I. W. (2005). Model Framing dan Belief Adjustment dalam Menjelaskan Bias Pengambilan Keputusan Pengauditan, Simposium Nasional Akuntansi VIII, Solo, September.

Trisnaningsih, S., \& Isnawati, S. (2003). Perbedaan Kinerja Auditor Dilihat dari Segi Gender.

Simposium Nasional Akuntansi VI., 1036-1047.

Trotman, K. T. (1997). Research Methods for Judgement and Decision Making Studies in Auditing, Coopers \& Lybrand.

Tversky, A., \& Kahneman, D. (1981). The Framing of Decision and The Psychology of Choice. Science, 211(30), 453-458.

Tuanakotta, T. M. (2011). Berpikir Kritis dalam Auditing. Jakarta, Indonesia: Salemba Empat

Undang-Undang No. 15 Tahun 2004 tentang Pemeriksaan Pengelolaan dan Tanggung Jawab Keuangan Negara.

Van Manen, M. (1990). Researching lived experience: Human science for an action sensitive pedagogy. London, ON, Canada: Althouse Press.

Willmott, H. (1993) Paradigms of Accounting Research: Critical Reflections on Tomkins and Groves: Everyday Accountant and Researching His Reality. Accounting, Organizations and Society, 18(4), 389-4 

0 Judgement State Auditor on Audit Opinion for Government. . . . .

Vol. 27, No. 2 August 2019

(C) Centre for Indonesian Accounting and Management Research Postgraduate Program, Brawijaya University 